\title{
The Design Improvement of Hip Implant for Total Hip Replacement (THR)
}

\author{
Solehuddin bin Shuib ${ }^{1}$, Barkawi bin Sahari ${ }^{2}$, Amran bin Ahmed Shokri ${ }^{3}$ and Chew Soon Chai ${ }^{1}$
}

\author{
${ }^{1}$ School of Mechanical Engineering, \\ Engineering Campus, Universiti Sains Malaysia, \\ 14300 Nibong Tebal, Seberang Perai, \\ Malaysia \\ Email:meshuib@eng.usm.my \\ ${ }^{2}$ Institute of Advanced Technology \\ Universiti Putra Malaysia, \\ 43400 Serdang, Selangor, \\ Malaysia \\ ${ }^{3}$ Department of Orthopedics \\ School of Medical Sciences, Health Campus \\ Universiti Sains Malaysia \\ 16150 Kubang Kerian, Kelantan, \\ Malaysia
}

Received Date: $28^{\text {th }}$ August 2006 Accepted Date: $7^{\text {th }}$ March 2007

\begin{abstract}
Hip implants are artificial joints that are made of metal such as titanium or stainless-steel, and have long stems which penetrate deep into the femur canal to hold them in place. It is generally used when there is biological damage in human hip joint. Research also shows that the number of person that underwent this type of surgical operation is increasing every year especially for the elderly with the age group of 65 and above. The purpose of this project is to study improvements on hip implant and propose a design that mostly fulfills the aspects for designing a hip implant. There are many aspects to consider in designing hip implant such as stiffness, implant characteristic and size of the implant. Materials are also one of the most important aspects in designing a hip implant because it has a positive relation to the stiffness of the implant. The materials that commonly used are Titanium and Stainless-steel. The analysis was performed by using COSMOSWorks Software. It helped in studying the reliability, failure and optimum stress that the newly designed implant can withstand. In this project, the results showed that the factor of safety (FOS) of the implant is 1.4.
\end{abstract}

Keywords: Hip implant, finite element analysis.

\section{ABSTRAK}

Alat ganti tulang paha adalah sendi palsu yang diperbuat daripada logam seperti Titanium atau besi tahan karat. la juga mempunyai tangkai (stem) panjang yang menembusi dalam ke saluran tulang paha untuk 
menahan ia pada tempatnya. la biasa digunakan apabila terdapat kerosakan biologi dalam sendi paha kita. Penyelidikan juga telah menunjukkan bilangan orang yang melakukan pembedahan jenis ini meningkat dari tahun ke tahun terutamanya bagi mereka yang menjangkau 65 tahun ke atas. Tujuan projek ini adalah untuk mengkaji tentang penambahbaikan terhadap alat ganti tulang paha dan cuba menghasilkan satu reka bentuk yang paling memenuhi aspek dalam mereka bentuk sebuah alat ganti tulang paha.Terdapat banyak aspekyang perlu kita pertimbangkan dalam mereka bentuk sesebuah alat ganti tulang paha seperti kekerasan, bentuk sifat pencucukan dan saiz. Bahan juga merupakan satu aspek yang penting dalam merekabentuk sesebuah alat ganti tulang paha kerana ia mengawal ciri-ciri bahan dan kekukuhan. Bahan yang biasa digunakan adalah Titanium dan besi tahan karat. Berdasarkan reka bentuk yang dihasilkan, analisis dilakukan terhadap reka bentuk berdasarkan tegangan dan kecacatan dengan menggunakan COSMOSWorks Software. Perisian ini telah membantu kebolehpercayaan, kegagalan, dan daya optimum yang dapat ditampung oleh alat ganti paha yang direka bentuk. Keputusan menunjukkan faktor keselamatan bagi alat ganti paha yang baru ialah 1.4.

Kata kunci: Alat ganti tulang paha, kaedah unsur terhingga.

\section{INTRODUCTION}

Hip implants are made of metal such as titanium or stainless-steel, and have long stems which penetrate deep into the femur canal (center of the thigh bone) to hold them in place. In a surgical operation known as Primary Total Hip Replacement (PTHR), the surgeon drills a hole down the femoral canal, and inserts the implant firmly into the hole, sometimes using special cement to ensure that the implant stays tightly fixed in place.

Typically, these implants begin to loosen, or otherwise fail, after 10-15 years, at which point the implant needs to be surgically replaced. This procedure is known as Revision Total Hip Replacement Surgery (RTHR). Actually, revision of prostheses is an expensive, sometimes dangerous and always psychologically costly for the patient, hence the procedure has to be avoided if possible. Mostly implant will fail because of these few effects like corrosion, wear, fatigue and other desirable agents. In this surgery, the failing orthopedic hip implant is replaced with a new one by removing the old implant, removing the bone cement, enlarging the implant cavity, and inserting the new implant. RTHR is more complex than PTHR: it requires more capabilities and has more uncertainty associated with it. Surgeons must plan for and remove the old implant and the old cement before cutting the new canal cavity. They must plan for the new cavity in the presence of the old implant and cement. This results in a longer surgery with greater risk to the patients.

So, a new design of hip implant will be carried out with higher reliability and durability. Few design parameters also will be added to increase its stability.

\section{LITERATURE REVIEW}

Although THR has been successful over 30 years, complications due to interface loosening and bone resorption in the calcar region still exist. One of the major issues is the effect of implant material properties on bone loss and interface loosening in THR (Katoozian et al. 2001). So, implant materials are one of the most important component of a hip implant design that can last long.

Most commonly, the long femoral element is made of stainless steel, Cobalt Chromium (Co-Cr) alloys, or Titanium ( $\mathrm{Ti}$ ) alloys. For a better performance, Ti alloys is suggested due to its improvement in wear properties in THR, compared with others materials. In addition to that, Ti alloys are also favorable for their impressive biocompatibility, high corrosion resistance and specific mechanical properties (Pohler 2000). Besides that, titanium implants are not ferromagnetic and do not cause harm to the patient in magnet resonance imaging (MRI) units. For internal fixation, titanium implants are always an alternative to stainless steel for patients who are allergic to nickel.

$\mathrm{Ti}$ alloys have lower modulus of elasticity when compared to Co-Cr-Mo alloys. Samiento et al. (1988) has compared the long term performance of these two different alloys as femoral components. With lower modulus stem, there was a significantly lower incidence of stress shielding. However this was at the expense of a significantly higher incidence of bone/cement interface radiolucency.

The application of bioactive coatings to $\mathrm{Ti}$ based alloys enhance the adhesion of $\mathrm{Ti}$ based implant to the existing bone, resulting in 
significantly better implant lifetime that can be achieved with materials in use today (Sloten et al. 1998).

Zirconia or zirconium oxide is the material of choice currently for ball heads because of its high strength and low wear rate (Affatato et al. 1999).

The first paper to report the use of zirconia in biomedical applications was in 1969 and the first paper illustrating the use of zirconia to manufacture ball heads for THR was reported in 1988 (Helmer and Driskell 1969). Considerable research has focused on zirconia and yttria ceramics that are characterized by fine grained microstructures. There are authors who propose ceramics ball head made of a mix of zirconium oxide and aluminium oxide claiming again higher of intraoperative femoral fractures during stem insertion. Bulleted geometry helps reduce distal point loading while creating a smooth transition zone for load transfer (McTighe et al. 2003).

\section{DESIGN DEVELOPMENT AND ANALYSIS}

From all the parameters and considerations that have been taken, here are the final designs that have been made as shown in Figure 1.

FE analysis was performed on the designed model for its stress distribution and deformation. Models were generated, analyzed and post processed using COSMOSWorks 4.0.

Based on the result obtained from simulation, it is not sufficient to prove that improvement has been made this model of hip implant.

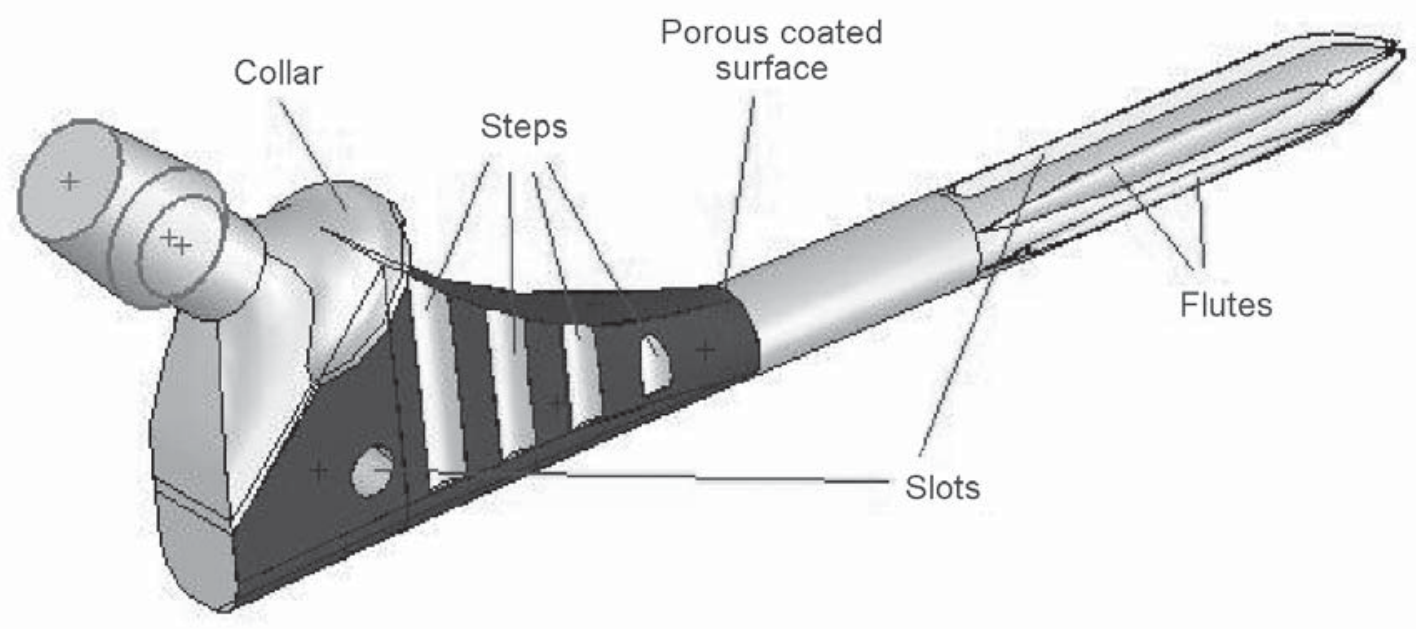

FIGURE 1. Final design with description

strengths and lower wear rates (Helmer and Driskell 1969).

There are four design parameters that have to be considered in designing the stem of hip implant namely shapes, steps, flutes and slots. To increase stem rotational stability, distal flutes have been incorporated into the stem design. Rotational stability remains the primary concern of any femoral component. These slots serve to reduce distal stem stiffness, allowing the stem to flex with the femur during normal daily activity. This feature has historically demonstrated reduced thigh pain (Cameron et al. 1990). In addition, it helps to reduce chances
Validation process has to be made by comparing the results from simulation with literature. By comparing the results, the differences between the proposed model with the existing model can be analyzed.

Mann et al. (1995) have carried out some research on loading cases in people walking especially during two conditions namely strenuous loading case and postoperative loading cases. Strenuous loading case was estimated based on loading in an active individual whereas postoperative loading was based on loading during patient rehabilitation period. The loads applied are as shown in Table 1. A body of 
weight of $750 \mathrm{~N}$ was used. The strenuous loading data was obtained from Paul (1967) and would represent gait in an active, and healthy individual. The postoperative loading cases were based on crutch-assisted gait data in a postoperative situation and were based on in vivo joint reaction force (Davy et al. 1988).

Besides, in order to make sure that the designed model can function well in any maximum stem was about 1.65 MPa. From stress distribution, it was seen that the maximum stress of the proposed design reached 373.4 $\mathrm{MPa}$ in the neck part. This value however, can not be compared with Mann et al. (1995) model, because it did not include the neck part during the simulation analysis. Therefore, only the stress at the edge of the stem can be compared. The results show that the stresses in the proposed

TABLE 1. Loading cases used in the finite element models

\begin{tabular}{ccccc}
\hline Loading case & $\begin{array}{c}\text { Head load } \\
\text { components } \\
\{\mathbf{x}, \mathbf{y}, \mathbf{z}\} \mathbf{( N )}\end{array}$ & $\begin{array}{c}\text { Head load } \\
\text { magnitude } \\
\mathbf{( x ~ B . W . )}\end{array}$ & $\begin{array}{c}\text { Greater } \\
\text { trochanter load } \\
\text { components } \\
\{\mathbf{x}, \mathbf{y}, \mathbf{z}\} \mathbf{( N )}\end{array}$ & $\begin{array}{c}\text { Greater } \\
\text { trochanter load } \\
\text { magnitude } \\
(\mathbf{x} \text { B.W.) }\end{array}$ \\
\hline Strenuous & $1492,915,-2925$ & 4.54 & $-1342,-832,2055$ & 3.45 \\
Postoperative & $460,439,-2008$ & 2.81 & $-310,-357,1138$ & 1.64 \\
\hline
\end{tabular}

TABLE 2. Muscle load magnitudes applied to the FE model. (El'Sheikh et al.2003)

\begin{tabular}{cccc}
\hline Force component (N) & Gluteus medius (N) & Gluteus minimus (N) & Ilio-tibial band (N) \\
\hline$F_{x}$ & -259 & -279 & -59 \\
$F_{y}$ & 160 & 269 & -74 \\
$F_{z}$ & 319 & 134 & -58 \\
\hline
\end{tabular}

These all loads can be resolved into:

$F_{x}=2188.86 \mathrm{~N}, F_{y}=-669.53 \mathrm{~N}, F_{z}=-5472.1 \mathrm{~N}$

condition, so the designed model is analyzed in stumbling condition. In this case, research done by El'Sheikh et al. (2003) on finite element simulation of the hip joint during stumbling was referred. The stumbling condition was chosen simply because it produces peak load during human activity.

For static analysis, the maximum stumbling resultant force, $F$, on the head of the femur is 8.7 times the body weight (BW $=70 \mathrm{~kg}$ ) at $58 \%$ of the gait cycle. Besides, El'Sheikh et al. (2003) also considered the muscle load magnitude applied to the FE model as shown in Table 2.

Since material is an important parameter that can affect performance of hip implant, the results for three main types of material for the stem were then compared.

\section{RESULTS}

Based on comparison between the results from the research of Mann et al. (1995) and that of proposed design, it can be seen that the maximum stress from Mann was approximately $220 \mathrm{MPa}$ while for the proposed design, the design are much lesser than Mann et al. (1995) model. This means that, further improvements are necessary in designing the hip implant.

For stumbling condition, the results from simulation are shown in Figures 2, 3, 4 .

There are three main materials that are generally used in the fabrication of the stem part of hip implant. For the same force applied, the results of displacement distribution and factor of safety (FOS) for these three kinds of material namely Titanium alloy (Ti6Al4V), Stainless Steel (316L) and Cobalt Chrome (CoNiCrMo) will be compared. Figures 5 shows the displacement for three different materials, where the maximum and the minimum displacement are shown. Figure 6 presents the results of the Factor of Safety (FOS) for these three kinds of materials.

\section{DISCUSSIONS}

Figure 2, shows that the maximum stress occurs at the neck of the stem was about $656 \mathrm{MPa}$. To ensure that the stem is safe to use, the factor of safety (FOS) distribution will be referred where it divides the stress on the element with the 
ultimate tensile strength of the Titanium alloy materials.

Figure 3 shows that the minimum FOS is at the critical part which is around 1.4. Generally, for design purposes, the value of FOS will be in the range of 1.2-1.5. This is to ensure that there are some tolerances on it. Figure 4 shows that the maximum displacement is $0.2434 \mathrm{~mm}$ and it occurs on the surface where the loads were applied. That value was considered small, therefore it can be neglected. Results of Figures $5,6,7$, were summarized in Table 3 .

The overall results show that the FOS is almost the same for these three kinds of materials. The value of FOS for Cobalt Chrome is double that of the Stainless Steel and Titanium alloy. Cobalt Chrome is the best material to be used in fabrication of hip implant.

\section{CONCLUSION}

Cementless hip implant has been chosen as the main factor in designing the implant fixation. It is believed that it can be long lasting compared to the cemented hip implant fixation due to the breaking up of cement particles. Another benefit of using cementless hip implant is that it is safer during revision surgery for hip replacement.

To avoid loosening of hip implant, few concepts have been added in the new design model in order to increase its stability. Flutes and steps are added to prevent the movement of hip implant and increase the fixation of hip implant. Slots are added to reduce bending stiffness of the implant.
To ensure that the designed implant work, validation has been made by comparing the results with earlier research. By applying the same boundary condition, the results showed that the stress developed on the designed implant are much more less than Mann et al. (1995) model. This proves that there are some improvements in the designed implant.

Analysis has also been done on different material used in implant. By applying the same condition of loading, the maximum displacement values are too small until can be neglected. Only for the value of FOS, the Cobalt Chrome has the value as high as 2.6.

For all the study and design that have done, it is believed that there are improvement of performance for the designed hip implant in the case of durability and reliability. However, in this project, the conclusion only can make from theoretical results. The main factor that influences the performance of hip implant such as wear rate cannot be determined in this project. In order to determine the wear rate, the best method is by fabricating a hip implant and inserting it in a patient's body. Using this experimental method, the actual wear rate of the hip implant can be calculated in order for the durability to be known.

\section{ACKNOWLEDGEMENTS}

The authors acknowledge support from USM short-term grant no. 6035120 .

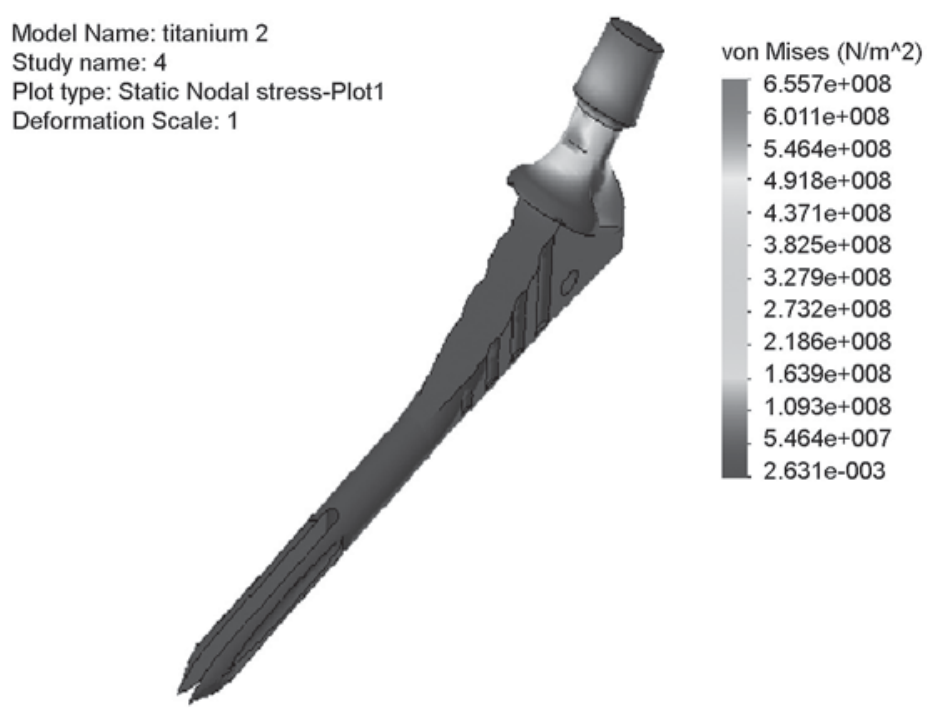

FIGURE 2. Stress distribution due to stumbling condition 
Model Name: titanium 2

Study name: 4

Plot type: Design Check-Plot1

Criterion: Max von Mises Stress

Factor of safety distribution: Min FOS $=1.4$

$1.000 \mathrm{e}+002$

$8.178 \mathrm{e}+001$

$8.356 \mathrm{e}+001$

$7.534 \mathrm{e}+001$

$6.712 \mathrm{e}+001$

$5.891 \mathrm{e}+001$

$5.069 \mathrm{e}+001$

$4.247 \mathrm{e}+001$

$3.425 \mathrm{e}+001$

$2.603 e+001$

$1.781 \mathrm{e}+001$

$9.592 \mathrm{e}+000$

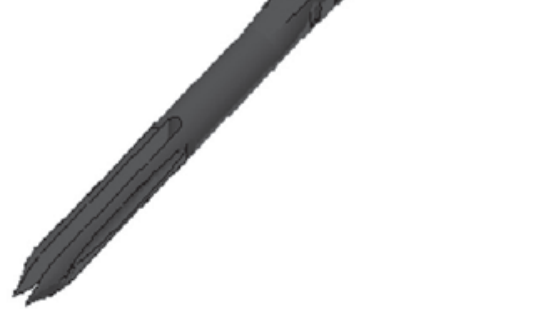

$1.373 e+000$

FIGURE 3. FOS distribution of designed hip implant

Model Name: titanium 2

Study name: 4

Plot type: Static displacement-Plot1

Deformation Scale: 1

URES (m)

$2.434 \mathrm{e}-004$

$2.231 \mathrm{e}-004$

2.029e-004

$1.826 \mathrm{e}-004$

$1.623 e-004$

$1.420 \mathrm{e}-004$

$1.217 \mathrm{e}-004$

$1.014 \mathrm{e}-004$

$8.114 \mathrm{e}-005$

$6.086 \mathrm{e}-005$

4.057e-005

$2.029 \mathrm{e}-005$

$1.000 \mathrm{e}-033$

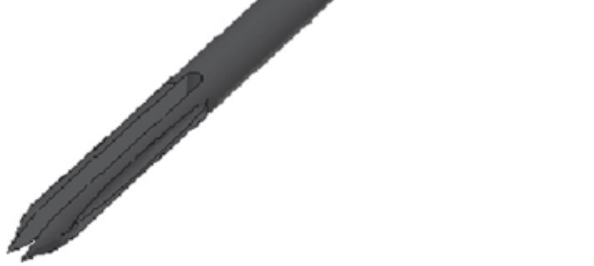

FIGURE 4. Displacement distribution of hip implant

URES (m)

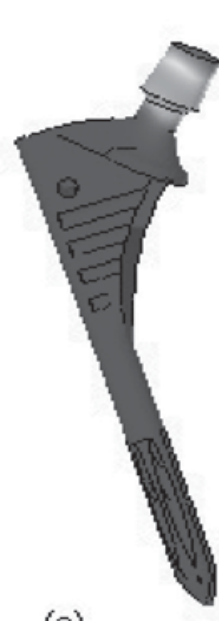

(a)

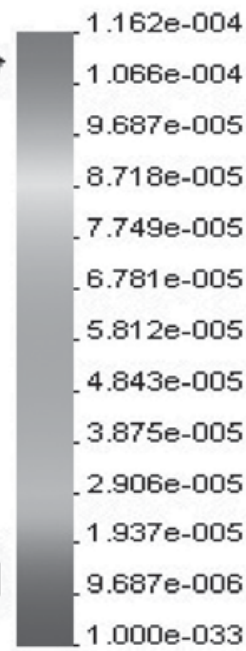

URES (m)

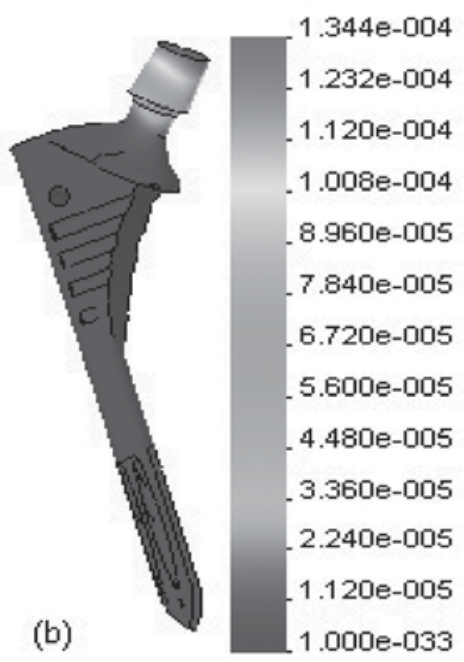

URES (m)

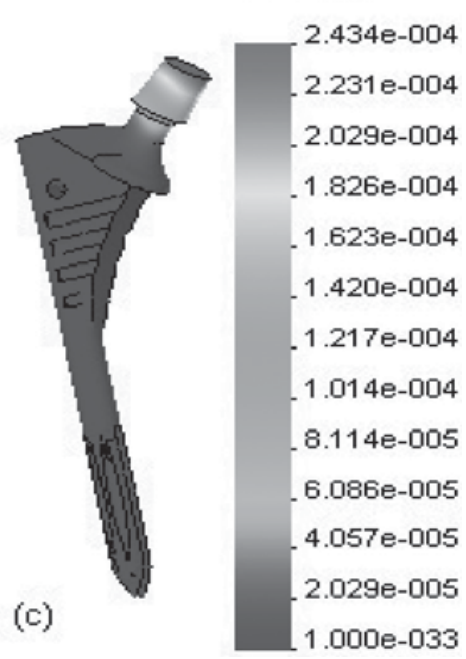

FIGURE 5. Displacement distribution for (a) Cobalt Chrome, (b) Stainless Steel and (c) Titanium alloy; where the maximum displacement are in the same place with the almost same value of (a) $1.16 \times 10^{-4} \mathrm{~m}$,

(b) $1.34 \times 10^{-4} \mathrm{~m}$ and (c) $2.43 \times 10^{-4} \mathrm{~m}$ 

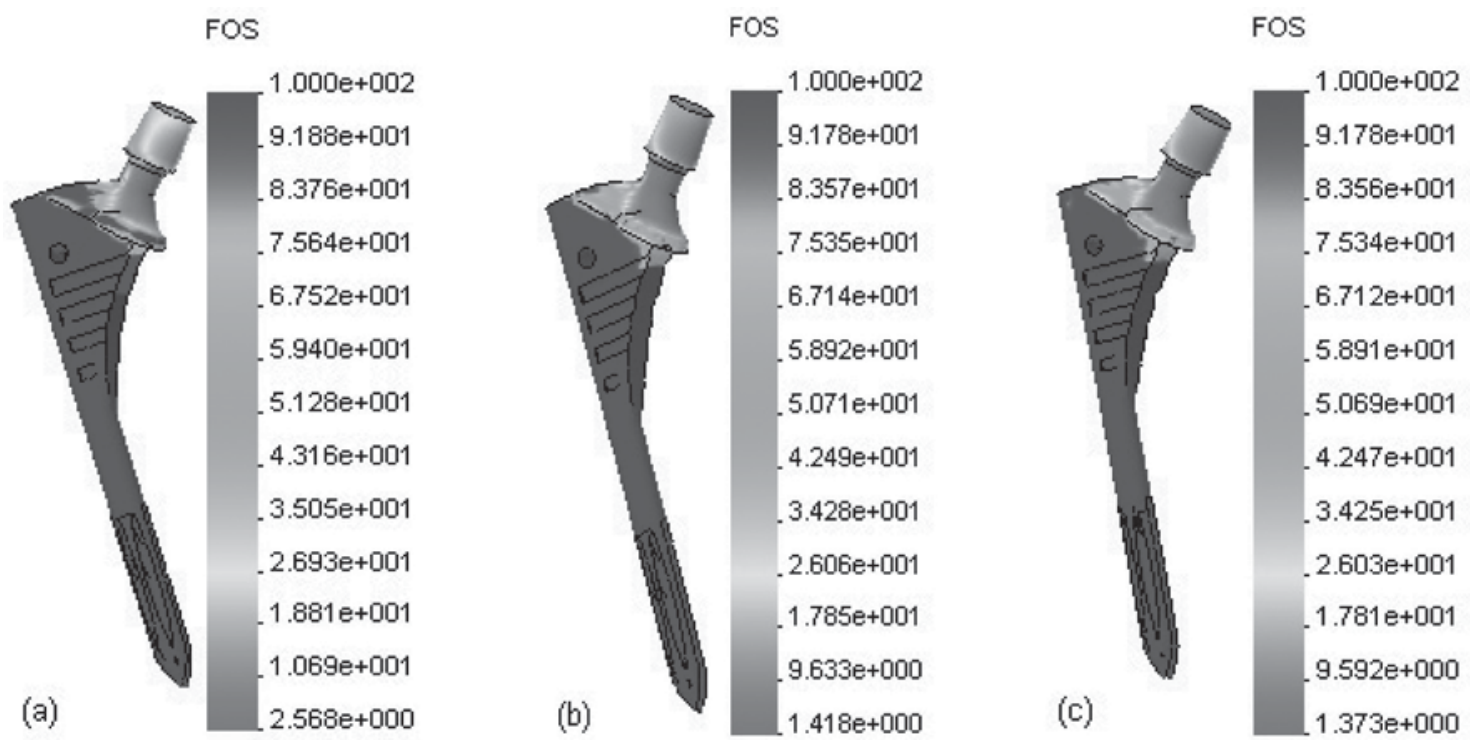

FIGURE 6. FOS distribution for (a) Cobalt Chrome, (b) Stainless Steel and (c) Titanium alloy; where the minimum FOS values are (a) 2.6, (b) 1.4 and (c) 1.4

TABLE 3. Results of simulation for different materials

\begin{tabular}{ccc}
\hline Materials & $\begin{array}{c}\text { Maximum } \\
\text { Displacement }(\mathbf{m})\end{array}$ & FOS \\
\hline Cobalt Chrome & $1.16 \times 10^{-4}$ & 2.6 \\
Stainless Steel & $1.34 \times 10^{-4}$ & 1.4 \\
Titanium Alloy & $2.43 \times 10^{-4}$ & 1.4 \\
\hline
\end{tabular}

\section{REFERENCES}

Affatato, S., Testoni, M., Cacciari, G.L. and Toni, A. 1999. Mixed oxides prosthetic ceramic ball heads. Part 1: effect of the $\mathrm{ZrO}_{2}$ fraction on the wear of ceramic on polyethylene joints. Journals of Biomaterials 20: 971-975.

Cameron, H.U., Trick, L.W., Shepherd, B.D., Turnbull. A., Noiles, D., and McTighe, T.1990. An international multi-center study on high in in total hip replacements. Scientific Exibit, AAOS Annual Meeting.

Davy, D.T., Kotzar, G.M., Brown, R.H., Heiple, K.G., Golberg,V.M. Heiple Jr, K.G.,Berilla, J.and Burstein A.H., 1988. Telemetric force measurements across the hip after total arthroplasty. J. Bone $\mathrm{Jt}$ Surg. 70A: 45-50.

El'Sheikh, H.F., MacDonald, B.J., and Hashmi, M.S.J.2003. Finite element simulation of the hip joint during stumbling: a comparison between static and dynamic loading.Journal of Materials Processing Technology, 143-144.

Helmer, J.D., and Driskell, T.D. 1969. Reseach in bioceramics, in: Proceedings of the Symposium on Use of Ceramics as Surgical Implants, Clemson University, SC, USA.

Katoozian, H., Davy, D.T., Arshi, A., and Saadati, U. 2001. Material optimization of femoral component of total hip prosthesis using fiber reinforced polymeric composites. Journal of Medical Engineering \& Physics, 503-509.

Mann, K.A., Bartel, D.L., Wright, T.M., and Burstein, A.H. 1995. Coulomb frictional interfaces in modeling cemented total hip replacements: A more realistic model. Journal of Biomechanics, Vol. 28, No. 9, pp. 1067-1078.

McTighe, T., Cameron, H.U., Smit, M., Reynolds, H.M., Keggi, K.J. 2003: Design Considerations For A Modular Neck In Total Hip Arthroplasty, World Congress on Osteoarthritis (OARSI), Berlin, Germany.

Paul,J.P.1967. Forces at the human hip joint, Ph.D.thesis, University of Glasgow, Glasgow, Scotland.

Pohler, O.E.M. 2000. Unalloyed titanium for implants in bone surgery, Injury, 31(4):7-13.

Samiento, A., Natarajan, V., Gruen, T.A., and McMahon, M. 1988. Radiographic performance of two different total hip cemented arthroplasties. A survivorship analysis. Orthop Clin North Am 19,505-515.

Sloten, J.V., Labey, L., Audekercke, R.V., and Perre, G.V. 1998. Materials selection and design for orthopaedic implants with improved longterm performance. Journal of Biomaterials 19 , 1455-1459. 